\title{
The exposure of the nursing profession in online and print media
}

\author{
Rodrigo José Martins Cardoso ${ }^{1}$ \\ João Manuel Garcia de Nascimento Graveto² \\ Ana Maria Correia Albuquerque Queiroz ${ }^{3}$
}

\begin{abstract}
Objective: to describe the coverage of news concerning the nursing profession in the Portuguese media: informative sites on the Internet and in print media. Method: a total of 1,271 health news items were collected in September and October of 2011 (956 online news items and 325 news items originating from the press review of the Portuguese Order of Nurses). Statistical analysis was used to characterize the variables. Results: nurses were the sources of information in $6.6 \%$ of cases, suggesting limited media exposure. The health news collected is characterized by a production based on limited information sources, that is, male and official sources, on information disseminated by news agencies focused on economic and political issues in the health field. Conclusion: the presence of nurses in the news concerning nursing health is reduced. We suggest that nurses develop public communication skills to disseminate the importance of their profession in society and their relationship with the media.
\end{abstract}

Descriptors: Nursing; News; Internet.

\footnotetext{
${ }^{1}$ Doctoral student, Instituto de Ciências Biomédicas Abel Salazar, Universidade do Porto, Porto, Portugal.

2 PhD, Adjunct Professor, Escola Superior de Enfermagem de Coimbra, Unidade Científico-Pedagógica de Enfermagem Fundamental, Coimbra, Portugal.

${ }^{3} \mathrm{PhD}$, Retired Profesor, Escola Superior de Enfermagem de Coimbra, Coimbra, Portugal.
}

Corresponding Author:

Rodrigo José Martins Cardoso

Av. Bissaya Barreto, 98

3000-075, Coimbra, Portugal

E-mail: rcardoso50@gmail.com
Copyright (c) 2014 Revista Latino-Americana de Enfermagem This is an Open Access article distributed under the terms of the Creative Commons Attribution Non-Commercial License (CC BY-NC).

This license lets others distribute, remix, tweak, and build upon your work non-commercially, and although their new works must also acknowledge you and be non-commercial, they don't have to license their derivative works on the same terms. 


\section{Introduction}

Nurses are the largest professional group in the health field in Portugal and have the responsibility to deliver safe and quality nursing care. The importance of these professionals has been confirmed by the production of scientific evidence showing a connection between nursing care and reduced rates of healthcareassociated infection, pressure ulcers, falls, deep venous thrombosis, and other indicators of morbidity and mortality ${ }^{(1-2)}$.

Care provided by nurses, however, tends to become blurred into the global delivery of healthcare, becoming almost indistinguishable by society ${ }^{(3-4)}$. Historical, social and cultural constraints have led nurses not to adequately disseminate the value of the care they deliver, which results in a low level of participation by these professionals in the public sphere (entertainment programs, health news and discussions concerning the delivery of healthcare and the healthcare system). Scientific publications reveal that the low visibility of nurses is not limited to Portugal. Countries such as England, the United States, Spain and Ireland also experience this same situation ${ }^{(3-5)}$.

This low exposure tends to emphasize the ambiguity that exists between nursing's social image and its recent development. The difficulty of nurses in talking in public is apparent and journalists seem to be unaware of the profession, seldom establishing contact with these professionals ${ }^{(6-7)}$. Additionally, lack of knowledge and existing stereotypes concerning nurses hinder society from valuing and acknowledging the work they perform. This lack of knowledge may negatively affect financial support provided for research and professional practice, consequently harming the health of citizens(7). Acknowledging this problem, many authors argue that nurses should acquire public communication skills in order to reaffirm the value and importance of the care they conceive, investigate and provide (8-9).

The visibility of nurses in social communication media, especially in the domain of health news in Portugal, has been an object of study of little interest. Some authors argue that the future of nursing is jeopardized if nurses are not able to communicate with the population and that the health of people will be at risk as a consequence of lacking appropriate care ${ }^{(7-10)}$. Because health news constitutes information that can influence the health choices of citizens, it is relevant to characterize the presence of nurses in the news.

\section{Objectives}

To describe the coverage of nursing professionals in Portuguese media: informative Internet sites and print media.

\section{Method}

This historical-documentary research study included a descriptive study, the objective of which was to describe the news coverage of the nursing profession in the recent past. A documentary study was conducted using as the primary source health news published online and in the print media (through preview review provided by the Portuguese Order of Nurses - OEP).

Data were collected from September $1^{\text {st }}$ to October $20^{\text {th }}$ of 2011 in alternate weeks, totaling 30 days.

Nine communication media outlets, the Internet sites of which were the most frequently visited in the semester prior to the data collection, were selected in the initial phase. In addition to access and storage capacity, which makes the Internet one of the privileged means to collect data, we verified that online issues are very similar to their print versions ${ }^{(11)}$.

Counts were made by means of Netscope, a sitecentric measurement system. The media websites most frequently visited in the semester were: Jornal Público (daily national newspaper); Jornal Expresso (weekly national newspaper); Jornal Destak (free daily newspaper); Revista Visão (weekly news magazine); Radio and Television of Portugal - RTP (TV channel; its website disseminates news produced by both RTP and RTP Notícias); TVI 24 (Independent channel; its website disseminates news from TVI and TVI 24); Sociedade Independente de Comunicação - SIC Online (TV Channel; its website disseminates news produced by both SIC and SIC Notícias); Rádio Renascença and Telefonia Sem Fios - TSF (these two stations are informative).

After selecting the media, we collected all the news related to health in a printed format. Due to temporal and methodological constraints, we did not include news in audio and video format.

The theoretical framework used in this study was based on the work of experts in the field(12-13). The variables of online health news items were established based on this study and on a method of triangulation with a panel of experts: theme (what motivated the news publication); journalistic genre (news, interview, article, and brief news); profession of the source of information; gender of the source of information and authorship (professional or institution/organization 
signs as the news item's author). Variables were also defined on the online news concerning nursing: type of media (where the article was published); information section (in which the article was published); theme; journalist genre; gender of the source of information; authorship (professional/organization that signs as the article's author); number of sources per news item (nursing sources), and number of news items (nursing news published per day, exposure in the news/day).

Since it is not the case that the entire Portuguese population has access to the Internet and more than $70 \%$ read newspapers or magazines ${ }^{(14)}$, we deemed it important to broaden the spectrum of investigation. According to a study conducted by the Observatory of Communication, the percentage of readers of online newspapers is significantly lower compared to print formats $^{(15)}$. Therefore, we defined and applied a second strategy to ensure representativeness of nursing news that is published in print media. These were obtained through press reviews provided by the OEP, available at the organization's website.

At the same time online news items were collected, we consulted the press review, available at the OEP's website (in the information tab - Press Review). The press review is obtained through articles available by the clipping company (scanned from the press segment in question). Then, the articles are sorted and organized by the OEP's Communication and Image Office. For the purpose of this investigation, only articles associated with the expression "Portuguese Order of Nurses" are used.

In this context, we defined a set of variables to characterize health news: theme, type of communication, number of sources and number of news items. Similar to online news, the choice was based on the literature and on the triangulation process previously mentioned. We considered the variables defined by the clipping company itself: type of media and scope of publication.

Data were treated using the statistical software Statistical Package for Social Sciences (SPSS) version 19. This software enabled the development of two databases (concerning the two research strategies), in which all the variables previously mentioned were included, as well as data concerning each health news items.

Ethical considerations concerning research conducted with human subjects do not apply because this study was solely based on health news.

\section{Results}

A total of 946 online health news items were collected. Of these, $57.3 \%(n=542)$ addressed issues concerning "Health Politics, Management and Economy", $18.4 \%(n=174)$ concerned "Scientific Investigation and Research", and 8.9\% ( $n=84)$ referred to "Public Health". The less frequently addressed themes were "Professional Practice" (7.6\%, $n=72)$, "Other" (isolated themes representing 3.5\%, $n=33)$, "Profession" (2.4\%, $n=23)$, "Education" (1.6\%, $n=15)$ and "Quality" $(0.3 \%, n=3)$.

Physicians (22.5\%, $\mathrm{n}=229)$ and politicians $(21.3 \%$, $\mathrm{n}=217$ ) were the main sources of information of online health news, as shown in Table 1 . Nurses were ranked sixth among the primary sources of information with $6.6 \%$ of the references $(n=67)$. We created the categories "other health professionals" and "other nonhealth professionals" to group professions that are seldom represented in health news. Some health news items had more than one profession as a source of information. For this reason, the number of professionals $(n=1,017)$ is higher than the number of health news items $(n=946)$.

Table 1 - Absolute and percentage distribution of the professions that were sources of information of online health news, Coimbra, Portugal, 2012

\begin{tabular}{lcc}
\hline \multicolumn{1}{c}{ Profissão da fonte de informação } & n & \% \\
\hline Physician & 229 & 22.5 \\
Politician & 217 & 21.3 \\
No profession is reported & 193 & 19.0 \\
Researcher & 94 & 9.2 \\
Management/Administrator & 85 & 8.4 \\
Nurse & 67 & 6.6 \\
Pharmacist & 51 & 5.0 \\
Other non-health professional & 44 & 4.3 \\
Other health professional & 32 & 3.2 \\
Journalist & 5 & 0.5 \\
Total & 1017 & 100 \\
\hline
\end{tabular}

In regard to the gender of the sources of information, more than half were male $(60 \%, n=562)$. Women alone were mentioned in $13 \%$ of the news $(n=126)$ and in $3 \%$ of the cases women were mentioned together with men $(n=31)$. The journalistic genres more frequently observed were News $(67.9 \%, n=642)$, followed by News brief (that which occupies half a page or three paragraphs, at most) with $32.1 \% \quad(n=304)$. Online health news items were credited to press agencies $(43 \%, n=410)$, by the media in which the news was 
published $(36 \%, n=341)$ or by the journalist who wrote the article $(21 \%, n=195)$.

Only 61 online news items addressed nurses or nursing; six were disregarded because their references to professions did not enable the description of the variables. Of these, $52.5 \%$ were published on websites of print media $(n=32), 39.3 \%$ was broadcasted on TV $(n=24)$ and $8.2 \%$ on the radio $(n=5)$. News addressing nursing was more frequently published in the "society" (36.1\%, $\mathrm{n}=22)$ or "health" $(18 \%, \mathrm{n}=11)$ sections, and on the "first or last pages" $(16.4 \%, n=10)$. In regard to the theme, we observe that nursing news mainly addressed "health policies, management and economy" issues $(65 \%, n=40)$, followed by news concerning the profession $(15 \%, n=9)$ and research, with $11 \%(n=7)$. The most frequent genre was News $(65.6 \%, n=40)$, followed by News brief with $34.4 \%(n=21)$. The gender of the source of information was not available in 22 nursing news items (36\%), while journalists tend to use press releases. Despite this fact, we observed that men are the main source of information (33\%, $n=20$ ) even though nursing is a profession in which women predominate $(26 \%, n=16)$. Press agencies are the most frequent authors of nursing news items (55.7\%, $n=34)$, followed by the media outlet itself $(24.6 \%, n=15)$, and journalists $(19.7 \%, n=12)$. We observed that a reduced number of information sources is used, with an average of 1.41 sources per item, with a standard deviation (SD) of 0.64 sources per news item. In regard to the number of news items published per day, an average of 3.59 items was observed ( $S D=2.4)$.

The 325 nursing news items gathered through OEP's press review (on the same dates of the online news versions), included part of the online publication and the print media. About half of the news reviews were published in regional newspapers $(49.5 \%, n=161)$, followed by national newspapers $(23.7 \%, n=77)$, online $(23.7 \%, n=47)$ and other publications (8.3\%, $n=27)$. In regard to the scope of publication, more than half of the articles addressing nursing belonged to the regional media $(51.1 \%, n=166)$, followed by general information $(21.5 \%, \mathrm{n}=70)$ and online information $(18.8 \%, \mathrm{n}=61)$.

The press reviews more frequently addressed work-related and market issues (19.1\%, $n=62)$ and then financial constraints in the health field $(10.8 \%$, $\mathrm{n}=35$ ). Issues concerning nursing education (10.8\%, $\mathrm{n}=35)$ and health education $(8.6 \%, \mathrm{n}=28)$ were also addressed. Half of the nurses' communications consisted of statements provided by professional institutions and individual nurses $(49.5 \%, n=161)$. Of these, most were from the OEP and unions, followed by profession/ professional brief citations $(28.6 \%, n=93)$ and articles written by nurses.

Nursing news items were obtained through the OEP's press review and an average of 1.46 sources per news item was observed $(S D=0.86)$, ranging from one to five sources. In regard to the number of news items per day, we observed an average of 10.83 news items published per day $(S D=6.59)$.

\section{Discussion}

The literature shows a reduced exposure of nurses in the media in various countries (England, the United States, Canada, Australia and Turkey) and that the discourse of nurses in health news is frequently pushed to the background or becomes invisible to the public eye $\mathrm{e}^{(3,7,9,16)}$.

This study's findings are in agreement with those found in the literature to the extent that they suggest a low exposure of Portuguese nurses in the media. These professionals rank as the sixth most common source of information of health news $(6.6 \%$ of the total, $n=67)$. One study published in 1999 reports similar conclusions, showing that nurses were mentioned in only $4 \%$ of health articles (only $1 \%$ in the specific cases of magazines and industry publications) ${ }^{(12)}$. A study that encompassed the analysis of 2,781 articles published by the Portuguese print media between 1990 and 2004, reports that nurses were mentioned in $4.4 \%$ of titles (and were personally mentioned in $1.7 \%$ ) and were sources of information in only $1.1 \%$ of the health articles ${ }^{(17)}$. Finally, confirming the findings previously mentioned, studies on health sources of information report that journalists show no interest in nurses and these are seldom mentioned individually or as an organization ${ }^{(13,18-19)}$.

This study suggests that physicians are the main source of information of health news $(22.5 \%, n=229)$. A similar finding is reported by a study that analyzed four Spanish newspapers in 2008. The author reports that the most cited sources in health articles were official or specialized sources, namely physicians ${ }^{(20)}$

Women were mentioned $13 \%$ of the time versus $60 \%$ of times in which men were cited. This information is in agreement with a Portuguese study showing that men were more frequently cited than women ${ }^{(13)}$. In this context, various authors argue that the continuing male hegemony in the discourse present in the media explains the low participation of women ${ }^{(13,18)}$. The journalistic genre most frequently observed was News 
(67.9\%, $n=642)$, which may be conditioned by the low development of Portuguese informative media on the Internet (low utilization of hypermedia and a belief in the use of breaking news)(11).

Nursing news reveals aspects that are similar to those observed in health news in regard to theme, journalist genre, gender of the information sources and authorship of health news items. Scientific investigation is addressed in only seven nursing news items, which may hinder society from understanding that professional practice is based on scientific evidence ${ }^{(7)}$.

The genre most frequently seen is News (65.6\%, $\mathrm{n}=40$ ) and men remain as the preferred sources of information. We note that, even though 50,841 women and 11,725 men were registered in the OEP, men are more frequently mentioned $(33 \%, \mathrm{n}=20)$ in online news (against the $26 \%$ that have cited women, $n=16)^{(21)}$.

News addressing health and disease tend to be reproduced from communication agencies and international agencies instead of being produced by the media that publish these articles ${ }^{(13)}$. The limited number of sources of information (average of 1.41) used in nursing news items suggests investigation in the course of the news process is shallow and reflects a systematic use of press agencies as a source of health articles.

News provided by the OEP's press review totaled 325 articles addressing nursing, which were published in the regional and national print media and in some online portals. Publications were concentrated in regional (49.5\%, $n=161$ ) and national $(23.7 \%, n=77$ ) newspapers, which may be explained by partnerships established by the OEP and some of these newspapers. These news items more frequently address the job market and labor issues in the nursing field (19.1\%, $\mathrm{n}=62)$, responses to financial cuts in healthcare $(10.8 \%$, $\mathrm{n}=35)$ and health policies $(9.5 \%, \mathrm{n}=31)$. The higher concentration of these themes may be related to the sociopolitical environment at the time of data collection and is in agreement with other studies in which nursing topics that are addressed by the media essentially focus on problem-issues ${ }^{(10)}$.

About half the citations concerning nursing were based on the statements provided by professional agencies, namely the OEP, unions, and nursing schools, which is corroborated by studies showing the preference of journalists for official and specialized sources ${ }^{(13,19)}$.

The average of 1.46 sources/news $(S D=0.86)$ in articles of the OEP's press review is not very different from the average observed for online nursing news. These results suggest there is little confrontation among opposite points of view and raise questions concerning the importance given by journalists and regarding the time they have available to dedicate to themes involving the profession.

Despite the number of health news items analyzed $(1,271)$, one should be careful in generalizing data since these concern a unique period in Portuguese history. The social events in a given period represent factors that influence the production of news, which may have conditioned these findings ${ }^{(22)}$.

\section{Conclusion}

The coverage of nursing news in Portugal on informative websites on the Internet and print media suggest a low exposure of nurses in the media. Nurses are seldom used as sources of information, while there is a preference for male sources from official institutions such as the OEP and unions. This investigation has limitations that implicate the need for critical reflection on the findings: screening performed by the OEP before publishing the press review; and the establishment of descriptors and historical and social constraints at the time of data collection. Further research including other media and analyzing the perception of social communication of professionals and nurses concerning the dissemination of nursing news would serve to confirm these findings.

The focus on health polities at the expense of investigation and the value associated with nursing care can impede society's knowledge of the essential contribution of these professionals to maintaining and improving health, preventing complications and reducing economic costs.

Nurses should break out of this spiral of silence and develop communication skills to improve their participation in public spaces. Only in this way will society come to know the profession's advancements, its social mission and the gains in health it generates, consequently enhancing the growth of a discipline essential to the health sector.

\section{References}

1. Schubert M, Clarke S, Aiken L, De Geest S. Association between rationing of nursing care and inpatient mortality in Swiss hospitals. Int J Qual Health Care. 2012;24(3):230-8.

2. Doran D. Nursing Outcomes. The State of the Science. $2^{\text {nd }}$. ed. Ontario: Jones \& Bartlett Learning; 2011. 522 p. 
3. Valero, C. La imagen de la enfermera a través de los medios de comunicación de masas: La prensa escrita. Index Enferm 2009;18(2):95-8.

4. Baggio M, Erdmann A. (In)visibilidade do cuidado e da profissão de enfermagem no espaço de relações. Acta Paul Enferm. 2010;23(6):745-50.

5. Summers S, Summers H. Saving Lives. Why the media's portrayal of nurses puts us all at risk. New York: Kaplan Publishing; 2009. 352 p.

6. Kemmer LF, Silva MJP. Nurses' visibility according to the perceptions of the communication professionals. Rev Latino-am Enfermagem. 2007;15(2):191-8.

7. Rezaei-Adaryani M, Salsali M, Mohammadi E. Nursing image: An evolutionary concept analysis. Contemp Nurse. 2012;43(1):81-9.

8. Chaffee M. Health Communications: Nursing Education for Increased Visibility and Effectiveness. J Prof Nurs. 2000;16(1):31-8.

9. Calvo M. Imagen social de las enfermeras y estrategias de comunicación pública para conseguir una imagen positiva. Index Enferm. 2011;20(3):184-8.

10. Cohen S, Bartholomew K. Our Image, Our Choice. Perspectives on shaping, empowering and elevating the nursing profession. Marblehead: HCPro; 2008. 139 p.

11. Canavilhas J. Os jornalistas online em Portugal. Biblioteca on-line de ciências da comunicação. [Internet]. 2005 [acesso 20 nov 2012]. Disponível em: http://www. bocc.ubi.pt/pag/canavilhas-joao-jornalistas-online.pdf 12. Sigma Theta Tau International. The Woodhull Study on Nursing and the Media: health care's invisible partner - Final Report. Revolution. 1998;8(2):64-70.

13. Lopes F, Ruão T, Marinho S, Araújo R. Jornalismo de Saúde e Fontes de Informação, uma análise dos jornais portugueses entre 2008 e 2010. Derecho a Comunicar. $2011 ;(2): 100-20$.

14. Grupo Marktest. 2a vaga de 2011 do Bareme Imprensa está disponível. [Internet]. 2011 [acesso 20 nov 2012]. Disponível em: http://www.marktest.com/ wap/a/n/id 17f1.aspx

15. Lima T. A Imprensa na Sociedade em Rede. Obercom [Internet]. 2011 [acesso 22 nov 2012]. Disponível em: http://www.obercom.pt/ client/? newsId=548\&fileName=fr_sr_julho_2011_ imprensa.pdf

16. Ertem G, Donmez Y, Oksel E. An Investigation of Nursing News in Turkish Daily Newspapers. Soc Behav Personal. 2010;38(5):577-82.

17. Silva PA. A Saúde nos Media. Representações do Sistema de Saúde e das Políticas Públicas na Imprensa Escrita Portuguesa. Lisboa: Mundos Sociais; 2011.
18. Lopes F, Ruão T, Pinto-Coelho Z. A doença em notícia: linhas de um projecto sobre a construção e monitorização da noticiabilidade sobre doenças. $8^{\circ}$ LUSOCOM Comunicação, espaço global e lusofonia. [Internet]. 14-18 abril 2009 [acesso 22 nov 2012]: p. 2190-203. Disponível em: http://conferencias.ulusofona.pt/ index.php/lusocom

19. Lopes F, Ruão T, Marinho S. Gripe A na Imprensa Portuguesa: uma doença em notícia através de uma organizada estratégia de comunicação. Observatorio J. 2010;4(4):139-56.

20. Sanchéz C. Medicina y salud en la prensa: las noticias de salud en los principales diarios de Galicia. Rev Latina Comunic Soc. 2008;63:15-21.

21. Ordem dos Enfermeiros (PT). Dados Estatísticos 2000-2010. 2011. [acesso 30 out 2012]. Disponível em: http://www.ordemenfermeiros.pt/membros/Documents/ OE\%20Dados\%20Estat\%C3\%ADsticos\%20-\%2020002010.pdf

22. Correia J. O admirável Mundo das Notícias: Teorias e Métodos. Covilhã: Livros LabCom; 2011. 241 p. 